\title{
RESPON NEGARA-NEGARA ASIA PASIFIK ATAS KEKERASAN TERHADAP PEREMPUAN PADA MASA PANDEMI COVID-19
}

\author{
Rekha Kersana \\ Program Studi Ilmu Hubungan Internasional, Universitas Pasundan \\ Email: rekha.kersana@unpas.ac.id \\ Rini Afriantari \\ Program Studi Ilmu Hubungan Internasional, Universitas Pasundan \\ Email: riniafriantari@gmail.com \\ Bulbul Abdurrahman \\ Program Studi Ilmu Hubungan Internasional, Universitas Pasundan \\ Email: bulbulabdurrahman@yahoo.co.id
}

\begin{abstract}
Non-traditional security issues are increasingly relevant in international relations discussions nowadays. Threats do not only come from the military aspect but could also come from the climate crisis, terrorism, and global pandemic. Recently, countries in the Asia Pacific faced a non-traditional threat, namely Covid-19, which threatens all aspects of humanity, especially health. At the same time, several countries have implemented lockdown, but this policy has resulted in violence against women. It is certainly an issue that countries must resolve in the Asia Pacific region, and UN Women as an international organization is responsible for issues concerning basic rights for women. In this study, the authors analyzed the response shown by countries in the Asia Pacific. The results of this study indicate that violence against women in the Asia Pacific was triggered by, among others: (1) the increasing interaction between victims and perpetrators, (2) environments that trigger acts of violence, and (3) limited support services. Thus, the authors examined how the policy responses of Asia Pacific countries in resolving the violence against women that occurred during the Covid-19 pandemic.
\end{abstract}

Keywords: Asia Pacific, Covid-19, Violence against Women, Policy Responses

\begin{abstract}
Abstrak
Isu kemanan non-tradisional semakin relevan dalam diskusi hubungan internasional dewasa ini. Ancaman saat ini bukan hanya datang dari aspek militer suatu negara saja, tetapi juga bisa datang dari krisis iklim, terorisme dan pandemi global. Seperti yang terjadi baru-baru ini, ancaman non-tradisional dihadapi oleh negara-negara Asia Pasifik, yakni Covid-19 yang mengancam seluruh aspek kemanusiaan, termasuk kesehatan. Bersamaan dengan itu, sejumlah negara menerapkan lockdown, akan tetapi kebijakan tersebut justru mengakibatkan terjadinya kekerasan terhadap perempuan. Hal ini tentu menjadi isu yang harus diselesaikan oleh negara-negara di kawasan Asia Pasifik, serta UN Women sebagai organisasi internasional yang bertanggung jawab pada persoalan menyangkut hak-hak dasar bagi kaum
\end{abstract}


perempuan. Dalam penelitian ini, penulis mengkaji respon yang ditunjukan oleh negaranegara di Asia Pasifik. Hasil penelitian ini menunjukan bahwa kekerasan terhadap perempuan di Asia Pasifik dipicu oleh diantaranya: (1) peningkatan interaksi antara korban dengan pelaku, (2) lingkungan yang memicu terjadinya tindak kekerasan, dan (3) layanan dukungan yang terbatas. Dengan demikian, penulis mencoba melakukan telaah tentang bagaimana respon kebijakan yang dilakukan negara-negara Asia Pasifik dalam menyelesaian kasus kekerasan terhadap perempuan yang terjadi pada masa pandemi Covid-19.

Kata Kunci: Asia Pasifik, Covid-19, Kekerasan terhadap Perempuan, Respon Kebijakan

\section{Pendahuluan}

Pandemi Covid-19 telah menjadi ancaman global saat ini. Hal tersebut memperkuat anggapan bahwa ancaman tidak hanya dapat dimaknai secara tradisional yang berfokus pada aspek militer semata. Dalam konteks modern, wabah dapat menjadi ancaman, seperti halnya krisis iklim, krisis pangan dan terorisme sehingga mengancam keselamatan manusia. Pandemi Covid-19 bermula pada Desember 2019 di Kota Wuhan, Provinsi Hubei, China dan dengan cepat menyebar ke seluruh dunia mengakibatkan terjadinya gelombang kematian penduduk global (Beaumont, 2020).

Ancaman pandemi Covid-19 tidak hanya mengancam kesehatan manusia. Dalam kasus lain, kondisi ini mendorong negara untuk menerapkan kebijakan lockdown dan memicu terjadinya gelombang resesi ekonomi global. Sebagai dampak kebijakan lockdown serta lesunya kegiatan industri perdagangan, International Labour Organization (ILO) menyebutkan sebanyak 114 juta orang harus kehilangan pekerjaan sepanjang tahun 2020. Lebih jauh, persoalan lain mengemuka, termasuk konflik keluarga yang berujung pada kekerasan terhadap perempuan akibat dari tekanan finansial yang harus dihadapi banyak kalangan (Richter, 2021).

Kekerasan terhadap perempuan juga terjadi di negara-negara Asia Pasifik selama pandemi Covid-19. Laporan yang berjudul "The Covid-19 Pandemic and Violence Against Women in Asia and the Pacific" dari Economic and Social Commission for Asia and the Pacific (ESCAP) menjelaskan tentang adanya dampak Covid-19 pada kekerasan terhadap perempuan yang terjadi di kawasan Asia Pasifik. Dalam laporan tersebut, kasus kekerasan terhadap perempuan yang 
terjadi di Asia Pasifik antara lain timbul dalam bentuk pemukulan, pelecehan seksual, hingga pemerkosaan. Faktorfaktor lain yang memicu terjadinya kekerasan terhadap perempuan selama pandemi Covid-19 diantaranya: (1) kebijakan lockdown yang membuat sekolah ditutup mendorong pada meningkatnya pernikahan anak usia dini; (2) lingkungan yang memicu stres para pelaku serta meningkatnya konsumsi alkohol; (3) keterbatasan akses terhadap layanan dukungan dan hukum, serta (4) stigma negatif bagi para penyintas kekerasan yang melakukan pelaporan (UN ESCAP, 2020).

Tulisan dari Susiana berjudul "Kekerasan Dalam Rumah Tangga Dalam Masa Pandemi Covid 19", memiliki kesesuaian dengan penelitian ini. Artikel

Grafik 1. Perempuan yang Mengalami Kekerasan oleh Pasangan di Asia Pasifik

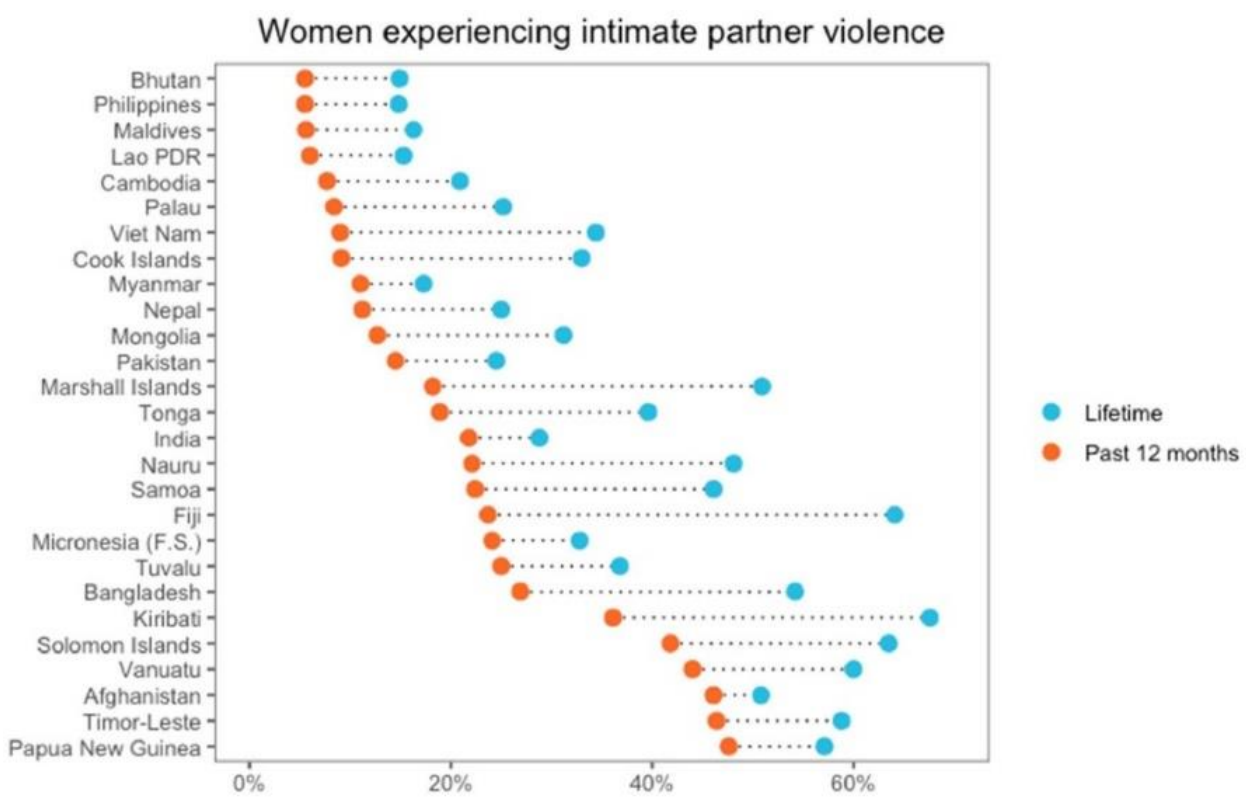

tersebut membahas tentang strategi penyebaran Covid-19 yang berdampak pemerintah melalui Kementerian pada kekerasan terhadap perempuan. Pemberdayaan Perempuan dan Sementara itu, upaya penanganan kasus Perlindungan Anak dalam menekan $\quad$ Kekerasan Dalam Rumah Tangga (KDRT) 
menghadapi tantangan pada masa pandemi (Susiana, 2020).

Dalam konteks Asia Pasifik, seperti yang telah dijelaskan sebelumnya, Covid19 memiliki implikasi pada kekerasan terhadap perempuan. Sehingga responrespon kebijakan yang dilakukan adalah sebagai berikut: (1) Memberi dukungan terhadap perempuan yang menjadi korban kekerasan; (2) Mebangun kesadaran bagi perempuan, khususnya dalam hal peradilan dan penegakan hukum; (3) Membangun fasilitas penampungan bagi para penyintas kekerasan; (4) Menghapus stigma agar para korban mau bersuara; (5) Meningkatkan digital literasi bagi perempuan; dan (5) Mendorong kemitraan antara pemerintah, organisasi masyarakat sipil dan organisasi internasional dalam penyelesaian masalah kekerasan terhadap perempuan (UN ESCAP, 2020). Dengan demikian, dalam bagian pembahasan akan dipaparkan tentang bagaimana respon serta kebijakan dari negara-negara Asia Pasifik dalam menyelesaikan kasus kekerasan terhadap perempuan selama pademi Covid-19.

\section{Landasan Teori}

Perspektif feminisme telah menjadi alternatif analisis dalam fenomena hubungan internasional kontemporer. Salah satu asumsi dasar teori feminisme adalah menyoroti tentang ketimpangan struktural antara perempuan dan laki-laki di mana hal tersebut menimbulkan banyak kerugian bagi pihak perempuan. Sebagai contoh, kekerasan kultural berbasis gender, stigmatisasi, hingga kekerasan fisik terhadap perempuan. Kalangan feminisme menilai pandangan patriarki masih sangat mendominasi beragam aspek dalam politik global. Patriarkisme tersebut tidak sedikit mempengaruhi struktur norma internasional yang mengesampingkan realitas perbedaan gender, termasuk dalam proses perumusan kebijakan tata kelola global. Dalam konteks ini, asumsi patriarki juga sangat memengaruhi struktur kebijakan untuk persoalan kesehatan, baik di level nasional dan internasional. Dampaknya, kondisi tersebut gagal melihat imbas pandemi yang dirasakan oleh perempuan (Wenham, 2021, p. 16).

Lebih jauh, kalangan feminis mengkritik diskursus keamanan dalam hubungan internasional yang gagal menjawab realitas representasi gender. Bagi kelompok feminis, penting untuk menempatkan perempuan dalam diskursus keamanan, kebijakan, serta bagaimana 
perempuan terdampak oleh dimensi keamanan tersebut (Wenham, 2021, p. 48).

Dalam kaitan antara feminisme dan keamanan kesehatan global, Wenham menyoroti tentang kondisi di mana perempuan menjadi pihak yang lebih rentan menanggun beban sosial-ekonomi selama wabah terjadi. Betul jika dikatakan bahwa wabah bisa menjangkiti siapa pun terlepas ia laki-laki atau perempuan. Namun, faktor konstruksi sosial membuat perempuan selalu menjadi kelompok yang lebih beresiko menanggung beban sosialekonomi tersebut. Selain itu, kegagalan memahami dimensi gender memengaruhi upaya respon kebijakan keamanan kesehatan yang sering kali tidak mengindahkan kaum perempuan. Kondisi tersebut secara berbeda sangat dirasakan oleh perempuan dalam situasi pandemi (Wenham, 2021, p. 4).

Dalam konteks kekerasan terhadap perempuan selama pandemi, Galtung mendefinisikan kekerasan sebagai setiap kondisi fisik, emosional, verbal, institusional, struktural atau spiritual, juga perilaku, sikap, kebijakan atau kondisi yang melemahkan, mendominasi atau menghancurkan diri kita sendiri dan orang lain (Webel \& Galtung, 2007). Dalam konsep kekerasan struktural, kondisi tersebut terjadi manakala lembaga dan struktur sosial, ekonomi, politik, hukum, agama dan kebudayaan di level global, nasional, hingga lokal, menyebabkan kerugian pada individu, kelompok atau masyarakat tertentu, dengan membatasi akses terhadap kebutuhan dasar mereka (Wenham, 2021, p. 145).

Dalam kasus Covid-19, pandemi sangat berdampak pada perempuan, termasuk dalam aspek ekonomi dan sosial. Pertama, pandemi membuat perempuan kehilangan pekerjaan akibat resesi ekonomi. Kedua, perempuan harus kehilangan pencaharian akibat tuntutan untuk mengurus anak di rumah. Ketiga, beban pekerjaan domestik yang bertambah selama pandemi. Keempat, beban ekstra bagi para ibu yang bekerja meningkatkan stres mereka. Terakhir, serangkaian kekerasan fisik dan psikis yang terjadi selama lockdown (Wenham, 2021, pp. 193-195). Dalam poin-poin selanjutnya, akan dipaparkan tentang bagaimana Covid-19 berimplikasi pada perempuan dalam aspek sosial, ekonomi, hingga pada meningkatnya kasus kekerasan terhadap perempuan di kawasan Asia Pasifik.

\section{Pembahasan}




\section{Implikasi Covid-19 pada Perempuan}

\section{Saat krisis pandemi Covid-19} terjadi, perempuan menjadi korban yang paling terdampak secara ekonomi dan sosial. Dalam konteks ekonomi, kebijakan penutupan sekolah dan pembatasan sosial membuat para perempuan memperoleh beban kerja domestik lebih banyak dari sebelumnya. Di samping itu, penelitian yang dilakukan oleh UN Women di Asia Pasifik menunjukan bahwa perempuan menjadi kelompok lebih rentan kehilangan mata penceharian dibandingkan dengan pria selama pandemi Covid-19 (UN Women, n.d.).

Dalam kasus Banglades dan India, perempuan menjadi pihak yang paling sedikit menerima informasi terkait Covid19. Hal tersebut disebabkan oleh minimnya kepemilikan telepon genggang dan jaringan internet sehingga akses terhadap informasi tersebut menjadi terhambat. Dampaknya, para perempuan tidak memperoleh informasi terkait protokol kesehatan. Sementara itu, pemahaman mereka terkait hal tersebut sangat dibutuhkan untuk mencegah penularan virus di level keluarga (UN Women Data Hub, 2020).
Perempuan dan gadis remaja tidak kalah menjadi korban selama pandemi, khususnya bagi mereka yang hidup di bawah garis kemiskinan. Angka putus sekolah bagi siswa perempuan meningkat sebagai dampak dari penutupan sekolah dan meningkatnya kebutuhan beban domestik di rumah. Mereka juga memiliki peluang lebih besar untuk terjerumus pada paksaan pernikahan dini sebagai upaya untuk meringankan beban ekonomi keluarga (UN Women, n.d.).

\section{Implikasi Covid-19 pada Kekerasan terhadap Perempuan di Asia Pasifik}

Di satu sisi lockdown diperlukan untuk memutus penyebaran virus Covid19, tetapi di sisi lain, kebijakan tersebut membatasi para perempuan untuk terhindar dari kekerasan domestik yang mereka alami. Sering kali kekerasan domestik terjadi di antara pasangan dan berlangsung di dalam rumah. Aturan untuk berdiam diri di rumah telah memicu terjadinya KDRT. Dengan tanpa adanya penanganan, para korban tidak memilik kesempatan untuk melarikan diri dari kekerasan yang mereka alami (UN ESCAP, 2020).

Kondisi semakin kompleks mana kala pihak berwenang dan warga mencoba 
patuh pada aturan lockdown yang diterapkan. Namun, secara bersamaan perempuan yang menjadi korban kekerasan tidak memiliki upaya untuk mencari bantuan atau melaporkan tindak kekerasan yang dialami. Tidak dapat dipungkiri bahwa kekerasan domestik akan memiliki dampak jangka panjang bagi korban dan anggota keluarga lainnya. Pandemi Covid-19 mungkin mereda, namun trauma atas kekerasan tersebut dapat berlanjut bahkan jauh setelah masa pandemi berakhir (UN ESCAP, 2020).

Dampak lain dari kebijakan lockdown yaitu adanya penutupan sekolahsekolah dan diterapkannya aturan belajar dari rumah. Mengacu pada data statistik ESCAP terbaru, jumlah perempuan berusia 20-24 tahun yang menikah sebelum usia 15 tahun berkisar antara 0 hingga 22,4 persen di Asia Pasifik. Bank Dunia mengemukakan bahwa cara terbaik untuk memutus angka pernikahan anak adalah dengan mendorong anak perempuan untuk tetap bersekolah (UN ESCAP, 2020).

Dengan adanya aturan belajar dari rumah sebagai upaya menghindari penyebaran virus Covid-19, justru meningkatkan resiko anak perempuan untuk menikah atau dinikahkan. Di sisi lain, anak perempuan yang menikah sebelum usia 18 tahun lebih rentan mengalami KDRT. Oleh karena itu, jika angka pernikahan anak meningkat sebagai akibat dari ditutupnya sekolah-sekolah, maka tentu hal tersebut akan beririsan dengan angka kekerasan domestik terhadap perempuan. Dalam konteks Asia Pasifik, pernikahan anak masih lumrah terjadi. Penutupan sekolah dapat membuat lebih banyak anak perempuan menjadi korban kekerasan (UN ESCAP, 2020).

Dalam kasus lain, para tenaga kesehatan sangat rentan mengalami kekerasan selama masa pandemi. Data menyebutkan 70 persen tenaga kesehatan, khususnya perawat, adalah perempuan. Tingginya kebutuhan akan layanan kesehatan selama pandemi membuat banyak perempuan tenaga kesehatan ada pada posisi yang lebih rentan (UN ESCAP, 2020).

World Health Organization (WHO) melaporkan bahwa 8-38 persen petugas kesehatan pernah mengalami kekerasan fisik dari pasien atau kerabat pasien. Di tengah kondisi stres yang diakibatkan oleh pandemi Covid-19, para tenaga kesehatan harus menghadapi pasien dan keluarga pasien sehingga membuat mereka berisiko 
lebih besar mengalami kekerasan (UN ESCAP, 2020). Laporan lain dari Insecurity Insight dan University of California menyebutkan bahwa ada sekitar 1.172 tindak kekerasan dan penyerangan terhadap tenaga kesehatan di seluruh dunia pada tahun 2020, di mana 412 diantaranya berkaitan dengan Covid-19 (FRANCE 24, 2021).

Mengambil India sebagai contoh, Accredited Social Health Activists (Ashas) melaporkan bahwa para tenaga kesehatan sering dilecehkan dan diserang selama masa pandemi Covid-19, di mana mayoritas yang mengalami pelecehan tersebut adalah perempuan. Selain itu, beban tugas yang tidak proporsional bagi perempuan membuat risiko terhadap tindak kekerasan menjadi jauh lebih besar (UN ESCAP, 2020).

Selama momen pandemi, banyak aktivitas dilakukan secara daring. Sebagai contoh, sekolah dan berkerja dilakukan jarak jauh sehingga meningkatkan jumlah waktu yang dihabiskan secara daring. Dampaknya, perempuan lagi-lagi menjadi pihak yang sangat rentan mendapat perlakuan kekerasan digital. Perempuan dewasa dan anak-anak memiliki kemungkinan lebih besar untuk mengalami pelecehan dunia maya (cyber harassment). Data statistik secara global menunjukan, 1 dari 10 perempuan mengalami cyber harassment di Uni Eropa. Sedangkan, 40 persen perempuan mengalami hal serupa di Pakistan. Sebagian besar aktivitas telah beralih secara daring, hal tersebut membuat semakin besar peluang bagi perempuan untuk mengalami kekerasan digital. Bentuk-bentuk kekerasa digital tersebut termasuk penyebaran foto tidak senonoh, komentar bernada seksis, ancaman fisik hingga penguntitan (UN ESCAP, 2020).

Kondisi pandemi ini tentu dilematis bagi perempuan. Peluang untuk menjadi korban kekerasan harus mereka alami, baik di rumah ataupun di dunia maya (Web Foundation, 2020). Selain itu, perempuan masih mengalami kesenjangan gender yang cukup kentara dalam hal akses terhadap teknologi informasi dan komunikasi. Secara global, jumlah pria yang menggunakan internet adalah 58,3 persen sedangkan perempuan hanya 48,4 persen. Dalam konteks kawasan Asia Pasifik, sebanyak 54,6 persen pria menjadi pengguna internet aktif, sedangkan perempuan hanya berkisar 41,3 persen (UN ESCAP, 2020). 
Literasi digital yang minim sebagai akibat dari kesenjangan tersebut membuat perempuan lebih rentan mengalami pelecehan. Sementara itu, kebutuhan dalam melakukan aktivitas daring bagi perempuan sangat tinggi selama pandemi. Saat aktivitas sekolah, bekerja dan kehidupan sosial dialihkan ke platform digital, ada lebih banyak peluang bagi pelaku untuk melakukan pelecehan dan penyerangan secara daring. Sedangkan, layanan dukungan bagi para korban kekerasan dilakukan secara daring selama lockdown (UN ESCAP, 2020).

\section{Rekomendasi Kebijakan atas Kasus}

\section{Kekerasan terhadap Perempuan selama}

\section{Pandemi Covid-19 di Asia Pasifik}

Pada poin ini akan dipaparkan mengenai rekomendasi-rekomendasi kebijakan dalam mengatasi persoalan kekerasan terhadap perempuan yang terjadi selama pandemi Covid-19 di kawasan Asia Pasifik.

\section{Dukungan bagi perempuan yang menjadi korban kekerasan}

Ketika aturan lockdown diberlakukan, hal tersebut secara drastis membatasi mobilitas masyarakat dan aktivitas ekonomi. Namun, di sisi lain, membuka jasa layanan untuk mekanisme pelaporan kekerasan terhadap perempuan merupakan hal yang penting untuk dilakukan. Dalam kasus tertentu, izin operasi dan perlindungan untuk menjamin keamanan sangat penting dilakukan bagi perempuan yang terpaksa meninggalkan rumah karena kekerasan domestik. Selain itu, layanan kesehatan rutin bagi perempuan sangat penting untuk terus diupayakan termasuk layanan keluarga berencana dan kesehatan reproduksi. Pendekatan-pendekatan tersebut menuntut para pembuat kebijakan untuk selalu menaruh perhatian pada aspek gender ketika menyusun kebijakan, khususnya pada saat pandemi terjadi (UN ESCAP, 2020).

\section{Membangun kesadaran perempuan} terhadap akses penegakan hukum dan peradilan

Dalam hal ini, polisi dan aparat penegak hukum perlu mengesampingkan aturan lockdown bagi mereka yang sedang menyelamatkan diri dari kekerasan domestik yang dialami. Peran lembaga penegak hukum sangat dibutuhkan dalam merespon kasus kekerasan terhadap perempuan demi menciptakan rasa aman bagi perempuan yang melaporkan kasus 
pelecehan pada mereka. Polisi dapat dilatih untuk mengidentifikasi korban kekerasan yang melarikan diri sehingga dapat memberikan perlindungan dan menghubungkan korban dengan layanan dukungan. Selain itu, sistem peradilan dapat mengambil langkah-langkah untuk meningkatkan akses terhadap pemulihan dan perlindungan, termasuk layanan konsultasi hukum virtual dan memperluas perlindungan bagi para penyintas kekerasan (UN ESCAP, 2020).

\section{Membangun fasilitas penampungan}

\section{bagi para penyintas kekerasan}

Dalam hal ini, pusat layanan dukungan dapat bermitra dengan hotel dan sekolah - mempertimbangkan kondisi banyaknya fasilitas publik yang tidak digunakan selama pandemi. Bangunan tersebut dapat dimanfaatkan untuk meningkatkan kapasitas tempat penampungan mengingat sebagian besar fasilitas tersebut kosong selama lockdown. Hal ini memerlukan adanya koordinasi antara organisasi masyarakat sipil, pemerintah daerah dan pelaku usaha lokal (UN ESCAP, 2020).

\section{Menghapus stigma agar perempuan} yang menjadi korban mau melapor dan bersuara

Alasan mengapa perempuan menolak untuk melaporkan pengalaman kekerasan yang mereka alami kepada pihak berwenang dan menahan diri untuk mencari bantuan adalah, salah satunya, karena adanya stigma yang melekat pada korban. Seperti yang dikemukakan oleh UN Women, pemerintah harus terlibat bersama dengan masyarakat - bukan hanya perempuan - untuk memerangi ketidaksetaraan dan stereotip berlandaskan gender sehingga melanggengkan praktik kekerasan terhadap perempuan (UN Women, 2020a). Memupus stereotip seputar pelaporan terhadap korban kekerasan merupakan langkah penting yang harus dilakukan.

\section{Mengembangkan metode inovatif} dalam sistem pelaporan tindak

\section{kekerasan}

Metode alternatif dalam hal sistem pelaporan harus dikembangkan. Dalam hal ini, sistem pelaporan tindak kekerasan dan proses pencarian dukungan harus dapat diakses oleh perempuan yang tidak dapat meninggalkan rumah untuk meminta bantuan. Media sosial merupakan platform 
yang dapat dimanfaatkan untuk melaporkan tindak kekerasan secara aktual. Selain itu, media tersebut juga dapat dimanfaatkan untuk menyebarkan kampanye dalam menentang stereotip dan diskriminasi gender. Selain itu, sinyal atau pesan tersirat seperti Red Dot Initiative merupakan contoh dari cara inovatif untuk menyediakan dukungan serta bantuan bagi para penyintas kekerasan (UN Women, 2020a).

\section{Meningkatkan literasi teknologi}

\section{informasi dan komunikasi bagi perempuan}

Risiko yang dihadapi oleh perempuan di dunia maya selama pandemi Covid-19 disebabkan oleh minimnya literasi platform digital. Pelatihanpelatihan perlu dikembangkan untuk meningkatkan pengetahuan perempuan tentang privasi dan keamanan digital (UN Women, 2020b).

\section{Mengembangkan metode pencegahan}

\section{kekerasan}

Metode pencegahan perlu untuk diupayakan selama pandemi. Layanan kesehatan mental harus disediakan selama lockdown. Hal tersebut dapat membantu meringankan stres atau tekanan psikis di antara pasangan yang sering memicu terjadinya kasus kekerasan domestik. Program bantuan ekonomi dari pemerintah seperti Bantuan Langsung Tunai (BLT) atau tunjangan bagi para pengangguran juga perlu diprioritaskan untuk mengurangi problem keuangan yang dapat memicu tekanan psikis dan kekerasan fisik (UN Women, 2020b).

\section{Mendorong kemitraan antara} pemerintah, organisasi masyarakat sipil dan organisasi internasional

Setiap rekomendasi kebijakan yang telah dipaparkan di atas memerlukan kerjasama antara pemerintah pusat, daerah, organisasi masyarakat sipil dan organisasi internasional. Dalam hal ini, PBB wajib memberikan dukungan ahli dan menjalin kerja sama dengan pemerintah. Kerja sama tersebut diantaranya: (1) memastikan keamanan ruang dan layanan publik, (2) bekerja dengan sektor swasta untuk memfasilitasi dukungan bagi karyawan yang mengalami kekerasan, dan (3) membantu organisasi masyarakat sipil dalam penyediaan layanan bagi para penyintas kekerasan. Selain itu, pemerintah harus mendapatkan bantuan yang diberikan oleh organisasi masyarakat sipil dan organisasi internasional demi 
mengurangi beban mereka selama pandemi Covid-19. Lebih jauh, upaya pencegahan kekerasan terhadap perempuan harus tetap menjadi prioritas pemerintah selama pandemi, sehingga memaksimalkan peran organisasi masyarakat sipil dan organisasi internasional sangat diperlukan (UN ESCAP, 2020).

\section{Respon dan Kebijakan yang Diambil Negara-negara Asia Pasifik}

Respon serta kebijakan yang diambil negara-negara Asia Pasifik dalam mengatasi kasus kekerasan terhadap perempuan selama pandemi Covid-19 dijelaskan sebagai berikut.

\section{Banglades}

Penanganan kasus kekerasan terhadap perempuan di Banglades ditekankan pada penyediaan layangan pengaduan. Misalnya, Banglades membentuk pusat pengaduan nasional bagi para pelaku pelanggaran hak asasi manusia di negara tersebut (UN ESCAP, 2020).

Selain itu, keterlibatan UN Women di Banglades sangat signifikan dalam hal pemberian dukungan bagi kelompok perempuan termarjinalkan yang terdampak pandemi di negara tersebut. Apalagi, Banglades merupakan negara penampung para pengungsi Rohingya. Sebagai contoh, ada setidaknya 800 perempuan di wilayah terpencil dan tempat pengungsian memperoleh akses terhadap ekonomi dan layanan kesehatan (UN WOMEN, 2020).

\section{India}

Upaya yang diambil dalam menyelesaikan kasus kekerasan terhadap perempuan di India diantaranya (UN ESCAP, 2020):

1) Kepolisian di Odisha menjalankan program untuk memantau para perempuan yang dilaporkan menjadi korban KDRT selama lockdown.

2) Kepolisian di Uttar Pradesh menyediakan layanan bantuan bagi para korban KDRT agar mendapatkan pendampingan khusus dari aparat perempuan.

3) Pemerintah Maharashtra merilis laman aplikasi dengan nama "Stand Up Against Violence" sebagai sistem pelaporan dan pendampingan. Dengan memanfaatkan kontak yang tersedia dalam aplikasi tersebut, para korban dapat terhubungan dengan aktivis, penyedia layanan bantuan hingga kelompok pergerakan perempuan untuk memperoleh dukungan serta pendampingan. 


\section{Indonesia}

Langkah yang dilakukan di Indonesia salah satunya dengan membentuk support group dari kalangan organisasi masyarakat sipil dan komunitas untuk para korban kekerasan seksual selama pandemi. Selain itu, kemitraan anatara UN Women dan Kementerian Pemberdayaan Perempuan dan Perlindungan Anak, dibentuk untuk mengembangkan suatu aturan yang berpusat pada hak asasi manusia dan korban dalam menangani kasus kekerasan berbasis gender (UN WOMEN, 2020).

\section{Kesimpulan}

tentang bagaimana pandemi Covid-19 dapat berimplikasi pada meningkatnya kekerasan terhadap perempuan. Sebelumnya, telah dipaparkan bahwa kekerasan terhadap perempuan di Asia Pasifik dipicu oleh diantaranya: (1) peningkatan interaksi antara korban dengan pelaku, (2) lingkungan yang memicu terjadinya tindak kekerasan, serta (3) layanan dukungan yang terbatas. Lebih jauh, telah dipaparkan mengenai rekomendasi-rekomendasi kebijakan dalam mengatasi persoalan kekerasan terhadap perempuan yang terjadi selama pandemi Covid-19 di kawasan Asia Pasifik. Beberapa diantaranya mencakup dukungan bagi korban, memupus stigma para korban kekerasan, hingga mendorong kemitraan antara pemerintah, organisasi masyarakat sipil dan organisasi internasional. Sementara itu, respon yang dilakukan oleh negara-negara Asia Pasifik sangat beragam diantaranya: 1) Penyediaan layangan pengaduan di Banglades, 2) Berbagai program inovatif dari aparat kepolisian dan pemerintah di India, dan 3) Kemitraan antara pemerintah, organisasi masyarakat sipil dan organisasi internasional dalam penanganan kasus kekerasan terhadap perempuan di Indonesia.

\section{Referensi}

Beaumont, P. (2020). Where did Covid-19 come from? What we know about its origins | World news | The Guardian. Theguardian.Com. https://www.theguardian.com/world/2 020/may/01/could-covid-19-bemanmade-what-we-know-aboutorigins-trump-chinese-labcoronavirus

FRANCE 24. (2021). Covid-19: More than 400 acts of violence against 
health workers in 2020. https://www.france24.com/en/africa/2 0210302-covid-19-more-than-400acts-of-violence-against-healthworkers-in-2020

Richter, F. (2021). How many jobs were lost in 2020 due to COVID-19? | World Economic Forum. World Economic Forum. https://www.weforum.org/agenda/202 1/02/covid-employment-global-jobloss/

Susiana, S. (2020). Kekerasan Dalam Rumah Tangga Pada Masa Pandemi Covid-19. Pusat Penelitian Badan Keahlian DPR RI, XII(24), 13-18. http://berkas.dpr.go.id/puslit/files/info _singkat/Info Singkat-XII-24-IIP3DI-Desember-2020-177.pdf

UN ESCAP. (2020). The Covid-19 Pandemic and Violence Against Women in Asia and the Pacific. Economic and Social Commission for Asia and the Pacific (ESCAP), 7387, $1-24$.

https://www.unescap.org/sites/default /files/20201123_SDD_Policy_Paper Covid-19-VAW.pdf

UN Women. (2020a). COVID-19 and Ending Violence Against Women and
Girls. UN Women Headquarters, 10. https://www.unwomen.org//media/headquarters/attachments/secti ons/library/publications/2020/issuebrief-covid-19-and-ending-violenceagainst-women-and-girlsen.pdf?la=en\&vs=5006

UN Women. (2020b). Online and ICT* Facilitated Violence against Women and Girls during COVID-19. https://www.unwomen.org//media/headquarters/attachments/secti ons/library/publications/2020/briefonline-and-ict-facilitated-violenceagainst-women-and-girls-duringcovid-19-en.pdf?la=en\&vs=2519

UN Women. (2020c). The First 100 Days of Covid-19 in Asia and the Pacific: a Gender Lens.

UN WOMEN. (2020). Standing Up to the Challenge: Response to the COVID19 Pandemic in Asia and the Pacific.

UN Women | Explainer: How COVID-19 impacts women and girls. (n.d.). Retrieved December 8, 2021, from https://interactive.unwomen.org/multi media/explainer/covid19/en/index.ht ml?gclid=CjwKCAiAhreNBhAYEiw AFGGKPCgZUwcNbccc1xIgUK0RT b19zuHqHnitjW3_pBCZnKnZod6FR 
JYZThoCiwUQAvD_BwE

UN Women Data Hub. (n.d.). Surveys show that COVID-19 has gendered effects in Asia and the Pacific. Retrieved December 9, 2021, from https://data.unwomen.org/resources/s urveys-show-covid-19-has-genderedeffects-asia-and-pacific

Web Foundation. (2020). There's a pandemic of online violence against women and girls - World Wide Web Foundation.

https://webfoundation.org/2020/07/th eres-a-pandemic-of-online-violenceagainst-women-and-girls/

Webel, C., \& Galtung, J. (2007). Handbook of Peace and Conflict Studies. In Handbook of Peace and Conflict Studies. Routledge Taylor \& Francis Group. https://doi.org/10.4324/97802030891 63

Wenham, C. (2021). Feminist Global Health Security. In Feminist Global Health Security. Oxford University Press.

https://doi.org/10.1093/oso/97801975 56931.001 .0001 